\title{
On sulphoxiphosvinic acid and its compounds
}

\section{Cloez}

To cite this article: M. Cloez (1847) On sulphoxiphosvinic acid and its compounds, Philosophical Magazine, 30:202, 382-382, DOI: 10.1080/14786444708647200

To link to this article: http://dx.doi.org/10.1080/14786444708647200

曲 Published online: 30 Apr 2009.

Submit your article to this journal ๔

Џ Article views: 2

Q View related articles $₫$ 
cold water; but if it be added to boiling water, it decomposes in. stantaneously, and the water contains pure soda only.

The author is of opinion that he has stated an important fact, which is, that the same oxide, by combining with different proportions of water, can form two acids which are distinguished by their properties, their equivalent, and their mode of combining with bases. -Journ. de Pharm. et de Ch., Mars 1847.

\section{ON SULPHOXIPHOSVINIC ACID AND ITS COMPOUNDS. BY M. CLOEZ.}

The author remarks that he and $M$. Bouyet had described a new kind of salts, the acid of which they designated sulphoxiarsenic acid, consisting of arsenic, oxygen and sulphur, water being deducted. The sulphoxiarseniate of potash, which was obtained by passing sulphuretted hydrogen into a solution of arseniate of potash, has for its formula $\mathrm{As} \mathrm{O}^{3} \mathrm{~S}^{2}, \mathrm{KO}+2 \mathrm{HO}$.

The great analogy existing between the corresponding compounds of arsenic and pliosphorus, rendered it probable that sulphoxiphosphates might also be formed. After many trials, M. Cloez succeeded in producing these salts by decomposing the chlorosulphuret of phosphorus of Serullas by an alkaline solution.

The chlorosulphuret of phosphorus, treated with common alcohol, yields an acid analogous to the phosphovinic acid of $\mathrm{M}$. Pelouze. According to $M$. Cloez the formula of this acid is $\mathrm{PhO}^{3} \mathrm{~S}^{2}, \mathrm{C}^{4} \mathrm{H}^{5} \mathrm{O}$, $2(\mathrm{HO})$; it is the sulphoxiphosphovinic acid. With pyroxylic spirit sulphoxiphosphomethylic acid is formed. Amylic alcohol should produce the corresponding compound, sulphoxiphosphanylic acid.

By saturating the sulphoxiphosphovinic acid with the carbonate of barytes, lime, strontia, \&c., well-defined crystalline salts are produced: the formula of the barytic salt is $\mathrm{PhO}^{3} \mathrm{~S}^{2}, \mathrm{C}^{4} \mathrm{H}^{6} \mathrm{O}, 2 \mathrm{BaO}+\mathrm{Aq}$.

The potash and soda salts are readily obtained by decomposing the chlorosulphuret of phosphorus with an alcoholic sulution of potash or soda. These salts are soluble in alcohol. The following equation explains the reaction which occurs with potash : $\mathrm{Ph} \mathrm{Cl}^{3} \mathrm{~S}^{2}$ $+\mathrm{C}^{4} \mathrm{H}^{6} \mathrm{O}^{2}+5(\mathrm{KO})=\mathrm{Ph} \mathrm{O}^{3} \mathrm{~S}^{2}, \mathrm{C}^{4} \mathrm{H}^{5} \mathrm{O} 2(\mathrm{KO})+3(\mathrm{KCl})+\mathrm{HO}$. Comptes Rendus, Mars 8, 1847.

\section{ON ANHYDROUS HYDKOFLUORIC ACID.}

M. Louyet states that in 1846 he mentioned to the Academy that, in his opinion, anhydrous hydrofluoric acid was as yet unknown; in proof of its correctness, he showed that the acid supposed to be so, saturated a smaller quantity of a base than it ought to do, if it had been anhydrous.

This proof not having satisfied M. Dumas, the author was advised by him to pass hydrofluoric acid, hitherto regarded as anhydrous, over anhydrous phosphoric acid, and to collect the product in a platina vessel immersed in a freezing mixture. According to $M$. Dumas, if by this process a liquid hydrofluoric acid was always ob- 